\title{
PERAN NEGARA DALAM EKSPANSI PT WIJAYA KARYA TBK KE AFRIKA: TINJAUAN KAPITALISME NEGARA
}

\author{
Anggi Mariatulkubtia Lubis \\ Program Pasca Sarjana Ilmu Hubungan Internasional, Universitas Indonesia, Indonesia; \\ anggi.mariatulkubtia@ui.ac.id
}

\begin{abstract}
This paper examines roles of the government in PT Wijaya Karya Tbk, (WIKA)'s active expansion to Africa from the perspective of state capitalism. This paper identifies the role of President Joko Widodo's regime in WIKA's expansion through (1) centralized planning, which determines target market and expansion goals; (2) economic diplomacy to open new markets and maintain relations and (3) capital assistance, with the state being WIKA's major stockholder. Through these findings, this paper argues that WIKA's expansion is aimed not only at generating profits, but is also influenced by political factors to spread influence in new markets and for electoral purposes. WIKA is positioned as the national champion in the infrastructure sector, which is deemed as a strategic industry for President Widodo's Regime. This paper is expected to fill the void of political economy research on the expansion of national SOEs abroad amidst the high needs of domestic infrastructure development.
\end{abstract}

Keywords: overseas expansion, SOEs, state capitalism, state role, WIKA.

\begin{abstract}
Abstrak
Tulisan ini mengkaji peran pemerintah dalam aktifnya ekspansi PT Wijaya Karya Tbk. (WIKA) ke Afrika dengan sudut pandang state capitalism. Lewat metode kualitatif deskriptif, tulisan ini mengidentifikasi peran Rezim Presiden Joko Widodo lewat (1). Perencanaan tersentral dalam menentukan tujuan dan lokasi ekspansi; (2). Diplomasi ekonomi untuk membuka pasar dan menjaga hubungan dengan pemerintah di negara tujuan, serta (3). Bantuan permodalan, mengingat posisi pemerintah sebagai pemegang saham terbesar. Berdasarkan temuan tersebut, tulisan ini berargumen bahwa ekspansi WIKA tidaklah semata-mata dilakukan dalam upaya mencari keuntungan, namun juga dipengaruhi oleh faktor politik dan dorongan negara untuk memenuhi kepentingan nasional, termasuk perluasan pengaruh ke pasar baru dan kepentingan elektoral. WIKA menjadi ujung tombak bagi sektor konstruksi dan infrastruktur yang dianggap sebagai sektor unggulan bagi Rezim Presiden Widodo. Tulisan ini diharapkan dapat mengisi kekosongan penelitian ekonomi politik tentang ekspansi BUMN nasional ke luar negeri di tengah tingginya kebutuhan pembangunan infrastruktur domestik.
\end{abstract}

Kata kunci: BUMN, ekspansi, peran negara, state capitalism, WIKA. 


\section{Pendahuluan}

Selama dua kabinet berjalan pemerintahan Presiden Joko Widodo, ekspansi Badan Usaha Milik Negara (BUMN) ke mancanegara menjadi salah satu target prioritas yang diberikan Presiden Widodo kepada pejabat menteri BUMN. Menteri BUMN Erick Thohir mengemukakan bahwa ekspansi BUMN ke luar negeri menjadi pesan khusus yang diberikan Presiden Widodo kepadanya pada saat pelantikannya sebagai menteri pada tahun 2019. Sementara itu, Rini Soemarno - yang menjabat sebagai menteri BUMN sebelum Menteri Thohir - menegaskan pentingnya ekspansi BUMN ke tanah asing untuk mengangkat nama baik dan posisi Indonesia di mata internasional (Prasongko, 2018). Di lapangan, upaya ekspansi ini telah dilakukan semenjak beberapa tahun ke belakang, dengan negara-negara Afrika sebagai pasar tujuan, utamanya bagi BUMN yang berkiprah di sektor riil.

PT Wijaya Karya Tbk. (WIKA) merupakan salah satu BUMN yang giat mencari pasar di luar negeri. WIKA merupakan BUMN konstruksi yang terdaftar di Bursa Efek Indonesia (BEI), dengan aset terbesar dibandingkan perusahaan terbuka dalam industri serupa. Semenjak berdiri pada tahun 1960, WIKA tumbuh lewat dominasi dan efisiensinya dalam sejumlah pembangunan infrastruktur di dalam negeri. Pada salah satu laporan tahunannya, WIKA menuliskan bahwa strategi perseroan untuk mengembangkan usaha adalah dengan berfokus pada proyek-proyek domestik yang didanai Anggaran Pendapatan dan Belanja Negara (APBN), sembari mencari pasarpasar strategis di luar negeri (WIKA, 2016). Saat ini, WIKA telah menangani kontrak di sejumlah negara di Afrika, Timur Tengah, serta hampir semua negara di Asia Tenggara.

Gagasan WIKA untuk melakukan ekspansi ke pasar luar negeri sebetulnya telah dimulai sebelum Rezim Presiden Widodo. Dalam salah satu laporan tahunannya, WIKA menyatakan bahwa langkah ekspansinya ke pasar Asia Tenggara dimulai dengan Vision 2020, yang menargetkan perseroan menjadi perusahaan EPC (engineering, procurement and construction) terbesar di kawasan (WIKA, 2019a). Rekam jejak WIKA di Afrika juga telah dimulai dengan pembangunan jalan di Aljazair pada periode tahun 2007-2008. Namun demikian, perseroan baru mulai serius mencatatkan segmen geografis pendapatannya pada tahun 2018 silam, seiring dengan masifnya dorongan pemerintah terhadap ekspansi BUMN ke luar negeri. Pertumbuhan pendapatan WIKA dari aktivitasnya di mancanegara selama beberapa tahun terakhir pun relatif pesat. Tercatat, hingga kini pemasukan WIKA dari aktivitas konstruksi di luar negeri telah mencapai 9\% dari total pendapatan WIKA (Rossiana, 2019).

Afrika - terutama Afrika Barat - menjadi target utama WIKA, yang mengedepankan strategi untuk mengincar pasar-pasar berkembang yang tengah giat membangun. WIKA, dalam salah satu rilis medianya, menyatakan bahwa BUMN Indonesia dapat berpartisipasi aktif dan menjajaki proyek-proyek di Afrika mengingat tingginya kebutuhan infrastruktur di negara-negara dalam kontingen tersebut (WIKA, 2019c). Dalam dokumen resminya, WIKA mengungkapkan bahwa masterplan proyek strategis negara-negara di kawasan Afrika Barat dari tahun 2020-2045 di sektor infrastruktur, energi, telekomunikasi, dan rel kereta api diperkirakan mencapai US $\$ 119,8$ miliar. 
Untuk tahun 2020, WIKA telah menargetkan nilai kontrak asing sebesar Rp 6 triliun, yang mayoritas berasal dari negara-negara di Afrika. Pada tahun 2018, WIKA mencatatkan pertumbuhan laba tahunan dari investasi luar negerinya hingga $71 \%$ atau menjadi Rp 90,83 miliar (WIKA, 2019a).

Saat ini, WIKA tengah menangani sejumlah proyek di negara-negara Afrika. Proyek tersebut di antaranya adalah renovasi Istana Kepresidenan Niger, yang memberi pemasukan hingga Rp 370 miliar dalam kontrak WIKA di tahun 2018. Di luar dari proyek yang tengah berjalan tersebut, Niger juga mengajak WIKA berpartisipasi dalam rencana pembangunan pembangkit listrik, perumahan rakyat, serta rel kereta api sebagai bagian dari program rencana jangka panjang Trans Afrika (WIKA, 2017b). Di tahun yang sama, WIKA juga menjalin kontrak dengan Agence Nationale de l'Amélioration et du Développement du Logement (Badan Nasional Modernisasi dan Pengembangan Perumahan Aljazair) untuk membangun 1.400 rumah yang ditargetkan selesai pada September 2020, namun kini tengah mengalami perlambatan akibat situasi pandemi (Prima, 2020). Kontrak ini disepakati setelah pada proyek sebelumnya, WIKA membangun hampir 4.000 rumah dengan nilai kontrak Rp 1,5 triliun di negara tersebut. Selain itu, WIKA juga tengah mengerjakan satu proyek apartemen di Senegal, sebagai bagian dari kesepakatan pembangunan kawasan bisnis terpadu senilai US\$275,5 juta. Proyek ini merupakan kelanjutan dari kesepakatan bisnis antara Pemerintah Senegal, WIKA, dan Lembaga Pembiayaan Ekspor Indonesia (LPEI). Selain proyek-proyek tersebut, WIKA juga tengah menangani konstruksi sejumlah proyek infrastruktur dan industri di Tanzania (WIKA, 2019c).

Ekspansi WIKA yang pesat di luar negeri, dalam pengamatan penulis, tidaklah semata-mata mengandalkan strategi perusahaan. Penulis melihat adanya pola hubungan antara dorongan pemerintah terhadap ekspansi perseroan. Lewat sejumlah pernyataan di media, petinggi-petinggi WIKA mengafirmasi bahwa pertumbuhan pendapatan dan laba dari aktivitas di luar negeri banyak dipengaruhi oleh forum multilateral antara Indonesia dan negara-negara Afrika, yang digagas oleh Pemerintah Indonesia selama beberapa tahun ke belakang. WIKA menjadi salah satu dari beberapa BUMN yang diboyong pemerintah dalam pertemuan-pertemuan yang ditujukan untuk membuka pasar baru di kawasan tersebut. Dari kesepakatan yang terjadi di Indonesia-Africa Infrastructure Dialogue (IAID) pada tahun 2019, WIKA mendapatkan proyek di Zanzibar, Senegal, Tanzania, dan Pantai Gading (Kemlu RI, 2019b). Selain itu, dalam ekspansi pasarnya ke luar Indonesia, WIKA juga banyak disokong oleh kemudahan pendanaan dari Indonesia EximBank (LPEI), dan kerap difasilitasi oleh kementerian atau institusi lainnya milik negara dalam menghubungkan perusahaan dengan negara tujuan ekspansi (WIKA, 2019e).

Penulis melihat adanya anomali dari agresivitas ekspansi BUMN sektor riil di tengah maraknya pembangunan infrastruktur dan pasar yang masih terbuka lebar di dalam negeri. Widodo, sejak awal kepemimpinannya, menekankan pentingnya pembangunan infrastruktur untuk meningkatkan konektivitas dan pertumbuhan ekonomi. Perkiraan kebutuhan dana untuk pembangunan infrastruktur hingga 2024 mencapai Rp 6.445 triliun, dengan komposisi dana APBN sebesar 37\%, dana dari BUMN sebesar 37\%, dan sisanya dibiayai oleh pihak swasta (Rencana 
Pembangunan Jangka Menengah 2020-2024, 2019). Dalam upaya pengerjaan proyek infrastruktur ini, Widodo melihat BUMN sebagai agen pembangunan (Kim, 2019). Dorongan untuk melakukan ekspansi ini menjadi kontradiktif ketika disandingkan dengan kebutuhan akan modal kapital dan tenaga kerja yang tengah diperlukan oleh Indonesia. Karenanya, penelitian ini ditujukan untuk melihat kepentingan dan utamanya peran pemerintah Indonesia terhadap aktivitas WIKA di luar negeri.

Pembahasan mengenai peran negara dalam kaitannya dengan ekspansi perusahaan telah dikaji oleh beberapa akademisi. Sebagian literatur menunjukkan bagaimana globalisasi dan interdependensi tidaklah mengecilkan peran negara. (Weiss, 2003:26-30), misalnya, berargumen bagaimana fenomena tersebut justru memberi ruang bagi negara untuk menyesuaikan kebijakan dalam upaya penciptaan kesejahteraan dan keuntungan ekonomi. Senada, Bieling (2007:12-14) juga berargumen bagaimana globalisasi tidaklah melemahkan peran negara dan mendorong transformasi negara dalam mengelola perekonomiannya.

Lebih lanjut, kajian mengenai ekspansi BUMN suatu negara ke luar negeri telah dilakukan oleh sejumlah peneliti. Buku Cuervo-Cazurra (2017), laporan OECD (2016), serta tulisan Redding et al. (2018) membahas secara detail bagaimana proses internasionalisasi BUMN berlangsung, hambatan dan kesempatan, serta keterlibatan negara di dalamnya. Sementara itu, studi kasus mengenai ekspansi BUMN ke luar negeri umumnya membahas mengenai perusahaan-perusahaan di Cina (Duckett, 2007).

Namun demikian, kajian ekonomi politik mengenai ekspansi BUMN Indonesia ke luar negeri masih sulit ditemukan. Sebagian besar pembahasan mengenai ekspansi BUMN masih berfokus pada upaya privatisasi. Kim (2019), misalnya, membahas bagaimana Rezim Presiden Widodo menggunakan BUMN sebagai agen pembangunan. Sementara itu, Carney dan HamiltonHart (2015) membahas bagaimana signifikansi bisnis BUMN meningkat setelah kejatuhan Orde Baru. Namun demikian, kedua tulisan tersebut belum mengelaborasi lebih lanjut mengenai agenda ekspansi BUMN ke luar negeri selama Rezim Presiden Widodo dan membuka peluang bagi penelitian yang lebih spesifik dan dalam. Selain itu, kajian yang membahas ekspansi WIKA secara lebih banyak berkaitan dengan studi mengenai strategi perusahaan dalam ranah ilmu ekonomi dan minim pembahasan mengenai dimensi politiknya. Terkait ekspansi WIKA, tulisan ini belum menemukan adanya jurnal atau karya ilmiah yang mencoba melihat peran negara dan membedah dimensi ekonomi politik dari fenomena tersebut. Tulisan ini hanya menemukan satu karya ilmiah (Purwanto dan Susanto, 2012) mengenai fenomena ekspansi ini dari kacamata ilmu ekonomi dan manajemen perusahaan.

Berdasarkan pemaparan di atas, pertanyaan penelitian dalam tulisan ini adalah "bagaimana peran Pemerintah Indonesia dalam mendorong ekspansi WIKA di negara-negara Afrika?". Tulisan ini ditujukan untuk mengisi gap dari minimnya kajian ekonomi politik mengenai peran pemerintah Indonesia dalam ekspansi BUMN ke luar negeri. Selain itu, tulisan ini diharapkan dapat memberikan kontribusi dan menjadi referensi mengenai dimensi politik dalam ekspansi BUMN 
ke luar negeri, relasi antara pemerintah dan BUMN, dan kontribusinya terhadap pembangunan ekonomi di Indonesia.

\section{Kapitalisme Negara (State Capitalism)}

Fenomena pengaruh antara globalisasi dan peningkatan peran negara dalam perekonomian telah dijustifikasi Weiss dalam bukunya," States in the Global Economy: Bringing Domestic Institutions Back In" (2003: 26-27). Menurut Weiss, globalisasi tidaklah menjadi hambatan bagi negara dalam mengelola perekonomian. Globalisasi, menurut Weiss, justru mendorong negara untuk memaksimalkan kebijakan ekonominya (enabling). Argumen Weiss didasarkan pada dua hal. Pertama, terpaparnya negara terhadap pasar mendorong pemerintah untuk meningkatkan proteksi sosial. Kedua, peningkatan kompetisi mendorong negara untuk menyediakan akses terhadap inovasi, suplai tenaga kerja, serta infrastruktur lainnya yang diperlukan oleh bisnis kompetitif.

Berkebalikan dengan ekspektasi akan menguatnya pasar bebas dan liberalisme ekonomi pasca berakhirnya Perang Dingin, sejumlah literatur mengamati adanya peningkatan keterlibatan negara dalam ekonomi global. Keterlibatan ini terlihat dari berkembangnya studi mengenai kapitalisme komparatif di Cina dan ekonomi berkembang lainnya, terutama setelah jatuhnya Lehman Brothers dan goncangan krisis finansial global tahun 2008 (Alami \& Dixon, 2019; Bremmer, 2010; Niall Ferguson, 2012). Nölke (2014) dan Sperber (2019) mengamati adanya tiga gelombang state capitalism yang awalnya identik dengan pemikir Marxist, beralih menjadi bentuk proteksionisme AS dan Eropa Barat setelah Great Depression, dan kini lebih diasosiasikan dengan intervensi pemerintah di ekonomi berkembang dan relasi antara pemerintah dan perusahaan. Model keterlibatan ini kerap disebut sebagai state capitalism kontemporer yang tidak lagi erat dikaitkan dengan haluan politik kiri (Bremmer, 2010; Taylor, 2014), cenderung rekat dengan pendekatan neo-merkantilisme (Balaam \& Dillman, 2014; Taylor, 2014), dan memiliki satu kesamaan jelas di dalamnya: utilisasi BUMN sebagai national champions atau perusahaan unggulan negara (Carney, 2015; Chen et al., 2016; Huat, 2015; Kröger, 2012; Kurlantzick, 2016; Li et al., 2014; Musacchio et al., 2015; Nölke et al., 2015).

Utilisasi BUMN ini tergambar dalam definisi-definisi state capitalism yang dijabarkan dalam sejumlah literatur. Carney (2015:838) dan Kurlantzick (2016:9) mendeskripsikan state capitalism sebagai bentuk kepemilikan korporasi di tangan negara. Kurlantzick lebih jauh mengidentifikasi state capitalists sebagai negara-negara yang pemerintahnya memiliki saham atau pengaruh yang besar atas lebih dari sepertiga dari 500 perusahaan dengan pemasukan terbesar di negaranya. Situasi ini memberikan pemerintah kendali yang lebih besar atas sektor korporasi dibanding dengan negara-negara lain yang berorientasi pada pasar yang lebih bebas

Sejalan dengan pemikiran nasionalisme ekonomi/neo-merkantilisme pada umumnya, state capitalism mengintegrasikan peran pemerintah dengan pasar bebas. Taylor (2014: 342) mendefinisikan state capitalism sebagai moda produksi yang pada hakikatnya kapitalis - dengan 
adanya upah buruh, ekstraksi profit, dan hubungan pasar - namun memiliki karakteristik unik lewat kepemilikan pusat di negara, derajat perencanaan produksi atau investasi yang tersentralisasi, serta tujuan nasional yang tercermin lewat pembangunan ekonomi jangka panjang. Sementara itu, Tsai dan Naughton (2020: 2) menggambarkan bagaimana state capitalism mengombinasikan ekonomi pasar, pasar modal yang berkembang, kepemilikan besar negara dalam perusahaan, serta unsur ekonomi politik yang tercermin dari nosi nasionalisme yang kuat. Kurlantzick menambahkan bahwa di luar kepemilikan negara atas perusahaan-perusahaan nasional, perekonomian state capitalist masih tetap berorientasi pasar.

Dalam perekonomian state capitalist di masa kini, negara umumnya melihat intervensi ekonomi bukan sebagai perbaikan sementara, tapi sebagai faktor pokok dalam mencapai kesuksesan kebijakan dan perekonomian pemerintah dalam jangka panjang. Kurlantzick juga secara singkat membahas beberapa cara lain bagi state capitalists untuk mengarahkan perekonomian negara mereka dengan memperhatikan tuas-tuas pengendali perekonomian, seperti belanja pemerintah untuk infrastruktur, pengeluaran untuk kesejahteraan sosial, dan penggunaan bank-bank milik negara sebagai strategi pinjaman bagi perusahaan-perusahaan dalam industri strategis negara.

Penelusuran penulis terhadap berbagai literatur menemukan adanya kesamaan tema dalam praktek state capitalism yang dilakukan oleh ekonomi berkembang, yaitu penggunaan pasar bebas dan globalisasi tidak hanya sebagai upaya penciptaan keuntungan namun juga sebagai legitimasi politik dan medium penyebaran pengaruh. Argumen ini, di antaranya, dapat ditemukan dalam tulisan Carney (2015) dan Kim (2019). Carney berpendapat bahwasanya Cina mempraktekkan state capitalism dalam upaya perbaikan ekonomi untuk mempertahankan stabilitas finansial dan stabilitas rezim. Sementara itu, Kim berargumen bahwa BUMN dapat diberdayakan sebagai kontributor fiskal ataupun agen perubahan, serta adanya potensi nasionalisme ekonomi digunakan sebagai upaya menjembatani perbedaan dalam negeri. Lebih lanjut, Bremmer (2010) menuliskan bagaimana state capitalist menekankan pada kekayaan, investasi, serta badan usaha publik dalam rangka penciptaan pembangunan ekonomi yang berkelanjutan secara politik. Pemerintah negaranegara ini akan terus mengelola sektor-sektor perekonomian mereka untuk mempromosikan kepentingan nasional dan menguatkan posisi politik mereka.

Merebaknya state capitalism gaya baru di abad ke-21 dapat ditelisik dari kemunculan, pertumbuhan, dan penguatan BUMN dari berbagai ekonomi berkembang yang kini turut bersaing di kancah global. Bremmer (2010) menyebutkan bagaimana dalam kurun waktu 2004-2008, tercatat 117 BUMN dan perusahaan publik dari Brazil, Rusia, India, dan China (BRIC) yang masuk ke dalam daftar Forbes 500 untuk pertama kalinya. Fenomena ini tidak hanya eksklusif terjadi di negara berkembang. OECD mencatat bahwa di antara negara-negara anggotanya, terdapat 58 BUMN yang telah menjadi perusahaan terbuka dan 1.617 BUMN yang belum melantai di bursa efek. Kapitalisasi pasar dari perusahaan-perusahaan ini mencapai US\$632 miliar atau 32\% dari GDP kumpulan negara-negara tersebut (OECD, 2016). 
Negara berkembang menjadikan globalisasi ekonomi yang semakin kompetitif sebagai peluang untuk melakukan ekspansi BUMN mereka ke luar negeri. Evolusi BUMN umumnya terbagi menjadi tiga tahapan, yaitu institusionalisasi, privatisasi, dan internasionalisasi. Hasil temuan penelitian yang dilakukan oleh Redding et al. (2018) menunjukkan bagaimana BUMN di Asia telah berekspansi ke pasar global untuk mengamankan sumber daya alam, memperoleh akses terhadap teknologi, meningkatkan kinerja pasar keuangan, dan memperoleh lingkungan investasi yang baik. Karenanya, mereka mengidentifikasi kinerja dan strategi ekspansi BUMN ke luar negeri kerap dipengaruhi oleh transisi institusional, keamanan sumber daya, perkembangan pasar dalam negeri, serta legitimasi pemerintah.

Lagi-lagi, aktivitas ekspansi BUMN ke luar negeri tidak lepas dari keuntungan ganda politik dan ekonomi. Meckling et al. (2015: 4) memaparkan adanya argumen bahwa dalam proses internasionalisasi BUMN, terdapat bentuk tujuan top-down yang bersifat politik dari pemerintah ke perusahaan, dan tujuan bottom-up yang bersifat komersial yang berasal dari perusahaan ke pemerintah. Chen et al. (2016) dan Klimina (2014) menuliskan bagaimana semakin dekat relasi perusahaan tersebut dengan pemerintah, semakin erat pemerintah menyematkan tujuan politik di dalamnya. Chen et al. berargumen bahwa kepentingan politik ini dibentuk oleh kebutuhan untuk membina dan mengelola legitimasi institusi secara domestik dan memperoleh dukungan institusional dari negara. Proses internasionalisasi, karenanya, muncul dari tujuan ganda ekonomi dan politik dari pemerintah. Sementara, Klimina menambahkan bagaimana pemerintah menyadari bahwa BUMN yang menghasilkan profit dapat membuat negara menjadi lebih kuat dan karenanya berupaya membangun global champions, yaitu perusahaan strategis yang menerima stimulus keuangan dan keunggulan komparatif lain yang tidak dinikmati perusahaan swasta. Ekspansi ke tanah asing kerap dilakukan oleh pemerintah sebagai alat diplomasi ekonomi yang didukung oleh kebijakan-kebijakan makroekonomi. Singkatnya, pemerintah kerap terlibat dalam ekspansi BUMN ke luar negeri, baik secara langsung maupun tidak, untuk mengejar kepentingan nasionalnya.

Terlepas dari tujuan ganda dalam ekspansi BUMN ke luar negeri, pemerintah dapat menjadi katalis bagi aktivitas perusahaan di tanah asing. Babic et al. (2019) mencatat bagaimana negara tidak hanya dapat meregulasi, memungkinkan, atau menahan kekuatan korporasi, namun juga bertindak sebagai aktor dalam ekonomi global ketika dikaitkan dengan kepemilikan sahamnya di BUMN multinasional. Chen et al. (2016) menegaskan bahwa state capitalism memiliki efek positif dalam mempengaruhi ritme internasionalisasi BUMN. Hal tersebut dapat dikaitkan dengan pemikiran Cuervo-Cazurra (2017), yang menegaskan bagaimana BUMN yang berekspansi ke luar negeri berbeda dari perusahaan multinasional tradisional lainnya, utamanya karena adanya kepemilikan negara, koneksi politik, dan kontrol negara sebagai poin krusial dalam mendorong BUMN untuk melakukan internasionalisasi dan berkompetisi di pasar global. Adanya kepemilikan negara ini memberi keuntungan bagi BUMN, misalnya dengan promosi dari pemerintah (Singh dan Chen, 2017), serta pemberian perlakuan istimewa dan dukungan dalam bentuk diplomasi ekonomi (OECD, 2016). 
Keterlibatan pemerintah mempengaruhi kemampuan dan kemauan perusahaan untuk melakukan internasionalisasi. Wang et al. (dalam Cuervo-Cazurra, 2017) berargumen bahwa keterlibatan pemerintah dalam internasionalisasi BUMN akan berpengaruh terhadap tingkat, lokasi, dan tipe investasi. Wang et al., lebih lanjut, memberikan enam indikator untuk melihat pengaruh pemerintah pada keputusan suatu perusahaan, yaitu dengan mempengaruhi (1) tujuan strategis dan keputusan perusahaan; (2) ketersediaan sumber daya; (3) bagaimana sumber daya ini dipergunakan; (4) kemampuan perusahaan; (5) penyediaan pengetahuan, informasi, dan layanan perantara; dan (6) biaya transaksi terkait ekspansi lintas batas.

Namun demikian, Alami dan Dixon (2019) memaparkan bagaimana state capitalism masih memiliki keterbatasan ruang dalam menyusun alat analisis. Hal ini karena adanya beragam definisi mengenai state capitalism. Definisi ini cenderung melibatkan cakupan luas instrumen kebijakan, belum menemukan konsensus mengenai derajat keterlibatan negara, kerap dikaitkan dengan sentimen geografis (Asia), serta deskripsi tujuan politik yang masih relatif sempit. Terlepas dari sejumlah kekurangan di atas, Alami dan Dixon melihat peluang mengembangkan konsep ini jika peneliti dapat menjembatani perbedaan-perbedaan antar kajian, utamanya dalam menemukan missing link dalam teori tersebut, periodesasi waktu, dan lokasi. Karena alasan tersebut, dalam menemukan variabel analisis yang tepat untuk menjawab pertanyaan penelitian dalam tulisan ini, tulisan ini akan mengerucutkan peran negara ke dalam variabel yang kerap berulang dalam kajian literatur tentang state capitalism.

Tulisan ini menemukan adanya tiga variabel intervensi negara yang kerap mendapatakan penekanan dalam kajian-kajian ilmiah mengenai state capitalism. Pertama, perencanaan tersentral dari pemerintah sebagai pemegang saham. Variabel ini akan membahas perencanaan negara yang di dalamnya memuat tujuan negara dan perusahaan dalam ekspansi, penentuan perusahaan sebagai national champion, serta penentuan lokasi dan konteks ekspansi (Babic et al., 2019; Carney \& Witt, 2014; Huat, 2015; Kurlantzick, 2016; Nölke et al., 2015; Taylor, 2014). Kedua, diplomasi ekonomi dalam upaya pembukaan pasar dan pembinaan hubungan baik dengan negara tujuan ekspansi (Chen et al., 2016; Cuervo-Cazurra, 2017; Klimina, 2014; Nölke et al., 2015; OECD, 2016). Menurut (Okano-Heijmans, 2011), diplomasi ekonomi merupakan penggunaan cara-cara politik untuk menguatkan posisi tawar dalam negosiasi internasional dalam rangka peningkatan kemakmuran ekonomi, serta penggunaan cara-cara ekonomi untuk meningkatkan stabilitas politik. Untuk dapat membahas secara rinci peran negara dalam ekspansi WIKA, penulis akan menggunakan kerangka analisis diplomasi korporasi yang dicetuskan oleh (Ordeix-Rigo \& Duarte, 2009), yaitu familiarity (perusahaan sebagai simbol negara dalam upaya pembukaan pasar dan membina hubungan baik), acceptance (penerimaan terhadap perusahaan karena adanya kesamaan nilai), serta engagement (pelibatan perusahaan untuk meningkatkan daya tarik perusahaan itu sendiri). Kerangka ini digunakan mengingat sebagai varian dari diplomasi ekonomi, diplomasi korporasi menekankan pada penggunaan perusahaan untuk mendukung kepentingan pemerintah dalam meraih legitimasi di luar negeri. Ketiga, penyediaan modal dan fasilitasi ekspansi oleh negara, yang merupakan salah satu bentuk intervensi mendasar dalam studi state capitalism 
(Carney \& Witt, 2014; Cuervo-Cazurra, 2017; Daniele, 2011; Huat, 2015; Klimina, 2014; Kurlantzick, 2016; Taylor, 2014).

\section{Metode Penelitian}

Penelitian ini merupakan penelitian kualitatif yang bersifat deskriptif. Data yang digunakan dalam penelitian ini merupakan data sekunder yang berasal dari dokumen resmi WIKA dan dokumen pemerintah, serta artikel jurnal dan pemberitaan dari media arus utama. Dalam analisisnya, tulisan menggunakan kacamata state capitalism dalam upaya mengidentfikasi peran negara sebagai pemegang saham dalam ekspansi BUMN ke luar negeri. Tulisan ini terlebih dahulu mengkaji sejumlah literatur terdahulu mengenai state capitalism. Kajian ini diperlukan untuk menghasilkan sintesis variabel-variabel penting dalam state capitalism, yang dapat digunakan untuk memetakan peran pemerintah dalam ekspansi BUMN. Terakhir, tulisan ini akan menganalisis peran pemerintah dalam sejumlah proyek WIKA di Afrika lewat sintesis variabel tersebut, setelah sebelumnya menjustifikasi status Indonesia sebagai state capitalist.

\section{State Capitalism dalam Peran Negara pada Ekspansi WIKA ke Afrika}

Sebelum lebih jauh membahas keterlibatan pemerintah Indonesia dalam ekspansi WIKA ke Afrika, tulisan ini akan membahas justifikasi Indonesia sebagai state capitalist. Peran negara dalam perekonomian terlihat dari operasi 115 BUMN di Indonesia (Kementerian BUMN; n.d.). Saat ini, terdapat 20 BUMN yang go public atau terdaftar sebagai perusahaan terbuka di Bursa Efek Indonesia (BEI), dengan kapitalisasi pasar lebih dari 25\% dari kapitalisasi pasar 690 perusahaan yang tercatat di BEI (Kementerian BUMN, n.d.; BEI, n.d.). Angka ini merupakan kenaikan hingga hampir 40\% sejak akhir 2014 dan belum mengikutsertakan anak usaha BUMN yang sahamnya diperdagangkan di BEI. Selain itu, tiga bank BUMN dan satu perusahaan telekomunikasi BUMN Indonesia masuk sebagai 1000 perusahaan publik terbesar versi Forbes (Kementerian BUMN, 2019).

Justifikasi Indonesia sebagai state capitalist juga telah dibahas dalam beberapa literatur. Kurlantzick (2016: 24), misalnya, memasukkan Indonesia ke dalam kategori democratic state capitalist. Lebih jauh, ia memosisikan Indonesia sebagai state capitalist terbesar kelima secara GDP, setelah negara-negara BRIC. Sementara itu, Kim (2019) menuliskan bagaimana Indonesia meningkatkan peran negara dalam perekonomian bertepatan dengan naiknya Rezim Presiden Widodo. Hal ini utamanya terlihat dari penekanan Presiden Widodo terhadap perlunya negara untuk memfasilitasi pembangunan infrastruktur dan reindustrialisasi. Kim secara khusus menyebut intervensi pemerintah Indonesia dalam perekonomian sebagai restrained state capitalism karena bentuk intervensi yang lebih longgar dibandingkan sebelum era krisis finansial Asia. Kim juga membahas penguatan BUMN sebagai strategi Rezim Presiden Widodo dalam menghadapi 
pemilihan umum 2019, dengan menekankan pembangunan infrastruktur serta menempatkan BUMN sebagai kebanggan nasional untuk menyenangkan konstituen dan menyatukan perbedaan politik. Dalam hemat tulisan ini, visi terhadap pembangunan infrastruktur, penekanan BUMN sebagai kebanggaan negara, dan upaya untuk memenangkan konstituen menjadi faktor politik yang mendorong ekspansi WIKA ke luar negeri. Pembahasan peran negara dalam ekspansi WIKA - yang melingkupi perencanaan tersentral, diplomasi ekonomi, dan bantuan modal - akan dijabarkan di bawah ini.

\section{Perencanaan tersentral}

Bagian ini akan membahas bagaimana peran pemerintah tidak saja memengaruhi internasionalisasi WIKA dan tujuan ekspansinya, namun juga pilihan lokasi sebagai sasaran ekspansi. Perencanaan tersentral ini tidak dapat dipisahkan dari tingkat kepemilikan negara di dalam perusahaan tersebut. Terlepas dari posisi WIKA yang telah melalui proses privatisasi dan terdaftar di BEI sejak 2007, pengaruh negara dalam mengarahkan ekspansi WIKA sangatlah besar, mengingat posisinya sebagai pemegang saham mayoritas dengan tingkat kepemilikan hingga 65\% (WIKA, 2020). Hal ini membuat pemerintah memiliki kekuatan untuk memilih maupun mencopot jajaran direksi WIKA serta mengarahkan kinerja perusahaan pelat merah tersebut. Selain itu, perencanaan tersentral juga terlihat dari pelibatan sejumlah institusi pemerintahan dalam ekspansi WIKA seperti Kementerian BUMN, Kementerian Keuangan Republik Indonesia (Kemkeu RI), Kementerian Luar Negeri Republik Indonesia (Kemlu RI), dan Lembaga Pembiayaan Ekspor Indonesia (LPEI).

Seperti yang telah dijabarkan pada pendahuluan dan kerangka konseptual di atas, ekspansi BUMN ke luar negeri memiliki tujuan ganda untuk menghasilkan keuntungan secara ekonomi sekaligus legitimasi politik. Penulis melihat bahwasanya Rezim Presiden Widodo mengarahkan WIKA dalam aktivitas ke luar negeri atas dasar dua keuntungan tersebut, serta menjadikan Afrika sebagai tujuan utama ekspansi terkait dengan target negara untuk membuka pasar baru nontradisional. Hal ini terlihat dari bagaimana ekspansi BUMN ke mancanegara menjadi prioritas yang diberikan Presiden Widodo secara langsung kepada kementerian BUMN, baik pada periode Kabinet Kerja (2014-2019) maupun pada Kabinet Indonesia Maju (2019-2024). Sementara itu, diplomasi ekonomi untuk membuka pasar baru non-tradisional telah digariskan sebagai salah satu dari empat arah kebijakan luar negeri Indonesia di lima tahun pertama kepemimpinan Presiden Widodo (Kemlu RI, 2015). Selama periode pertama pemerintahan Presiden Widodo, diplomasi ekonomi di dalam institusi Kemlu utamanya difokuskan pada pembukaan pasar non-tradisional di Afrika, Asia Tengah dan Asia Selatan, serta Amerika Latin.

Penempatan WIKA sebagai national champion atau BUMN strategis yang mendapatkan keuntungan komparatif untuk merambah pasar Afrika tidak lepas dari persepsi Rezim Presiden Widodo akan pentingnya pembangunan infrastruktur. Rezim Presiden Widodo melihat bahwa infrastruktur bukan hanya menjadi prioritas pembangunan dalam negeri, namun juga sebagai 
keunggulan kompetitif Indonesia yang siap dikembangkan di ranah internasional. Presiden Widodo menyebutkan Indonesia siap bekerja sama berbagi pengalaman dan saling membantu untuk pembangunan infrastruktur (CNN Indonesia; 2020). BUMN Indonesia, menurut Presiden Widodo, memiliki pengalaman dan kekuatan untuk membangun infrastruktur dalam kondisi geografis dan iklim yang ekstrim, yang ingin dibagi tidak hanya dengan rakyat Indonesia, namun juga Afrika. Di dalam negeri, pengalaman ini terlihat dari misalnya pembangunan sekitar $782 \mathrm{~km}$ jalan tol, $3.387 \mathrm{~km}$ jalan nasional, 191 ribu km jalan desa, 15 bendungan besar, 3,5 juta unit rumah, serta perbaikan 23 ribu hektare kawasan kumuh perkotaan dalam lima tahun pertamanya memimpin Indonesia. WIKA, sebagai BUMN konstruksi terbesar yang tercatat di bursa efek dan memperoleh akses finansial, menjadi ujung tombak Indonesia untuk ekspansinya di Afrika. Hingga kini, WIKA adalah satu-satunya BUMN yang telah menghasilkan profit dari aktivitasnya di luar negeri (WIKA, 2018b).

Dalam merangkum tujuan ekspansi Indonesia di Afrika secara umum, penulis melihat adanya capaian berupa profit dan perluasan pasar yang dikejar oleh negara dan perusahaan, serta tujuan legitimasi yang bersifat politik bagi pemerintah Indonesia. Jajaran direksi WIKA mengungkapkan perlunya WIKA untuk menjaga portofolio luar negeri di kisaran 10-12\% dari total pendapatan perusahaan, sebagai upaya pengembangan perusahaan dalam beberapa tahun ke depan. Hal ini dilandasi oleh proyeksi bahwa dalam delapan tahun ke depan, Indonesia akan menjadi pasar konstruksi terbesar keempat di dunia. WIKA perlu untuk terus mengembangkan portofolio proyek di luar negeri sebagai bagian dari industri global agar bisa bertahan kompetitif di tengah derasnya persaingan. Selain itu, menurut WIKA, gross margin proyek-proyek di luar negeri berkisar di antara 13-17\%, dibanding 10-12\% di level domestik (Pratomo, 2019). Hal ini sesuai dengan pemikiran Weiss (2003) yang menekankan adanya peran pemerintah dalam globalisasi dalam kaitannya dengan peningkatan kompetisi, serta pemikiran Kurlantzick (2016) mengenai state capitalism sebagai bentuk pemikiran jangka panjang.

Terlepas dari tujuan yang bersifat profit-making, Kemlu, Kementerian BUMN, dan WIKA juga kerap melemparkan pernyataan yang bersifat patriotis, yang sejalan dengan visi Presiden Widodo untuk memprioritaskan penyebaran pengaruh dan ekspansi pasar di Afrika. Mantan Direktur Utama WIKA Bintang Prabowo, misalnya, menyebutkan bahwa WIKA siap mengemban amanah Pemerintah Indonesia sebagai BUMN yang memiliki pengalaman berhasil mengerjakan proyek pembangunan infrastruktur di luar negeri, khususnya di Afrika (WIKA, 2017b). Sejumlah pernyataan seperti "berkontribusi pada bangsa dan negara" dan menghasilkan devisa, serta keinginan untuk mengalahkan pesaing dari Cina yang kerap disebutkan oleh jajaran direksi WIKA (Kumairoh, 2018; Prima, 2019) menunjukkan adanya tujuan tersentralisir yang diarahkan oleh negara, dan bukan sekadar perencanaan bisnis perusahaan semata. Selain itu, Mantan Menteri BUMN Soemarno juga menegaskan pentingnya ekspansi BUMN ke tanah asing untuk mengangkat nama baik dan posisi Indonesia di mata internasional (Prasongko, 2018). Selain itu, sejalan dengan pemikiran Bremmer (2010), Carney (2015) dan Kim (2019), nosi nasionalisme dalam utilisasi BUMN juga tidak lepas dari upaya mempertahankan stabilitas rezim, mengingat 
fragmentasi politik dan panasnya situasi di dalam negeri utamanya menjelang pemilihan presiden 2019 silam.

Sementara itu, hasil penelusuran penulis menunjukkan bahwa penempatan Afrika sebagai tujuan utama investasi WIKA oleh pemerintah didorong oleh beberapa faktor. Kemlu RI (2018) menegaskan bahwa masih terdapat banyak ruang untuk potensi pengembangan kerja sama ekonomi kedua negara, utamanya melihat nominal perdagangan 2016 antara Indonesia dan Afrika yang baru mencapai US\$7,66 miliar. Menurut Kemlu, ini adalah momentum yang tepat bagi kedua pihak untuk bersinergi, mengingat pertumbuhan ekonomi keduanya yang bisa saling mendukung. Indonesia, menurut PwC dan Asian Nikkei, akan bertumbuh menjadi ekonomi keempat terbesar dunia pada tahun 2050. Sementara, ekonomi Afrika sub-Sahara tumbuh sekitar 3,5\% pada tahun 2016, tertinggi kedua di dunia setelah Asia. Selain itu, dalam hal populasi, sekitar 62\% dari populasi Afrika berusia di bawah 25 tahun, yang menunjukkan ketersediaan tenaga kerja untuk membantu meningkatkan pertumbuhan ekonomi Afrika. Selain itu, saat ini terdapat sekitar 330 juta populasi kelas menengah di Afrika yang memiliki daya beli yang semakin kuat. Pengeluaran untuk infrastruktur meningkat dua kali lipat selama dekade terakhir dan sekarang mencapai 3,5\% dari GDP kontingen tersebut.

Selain penentuan tujuan dan lokasi ekspansi, perencanaan yang tersentralisasi juga dapat dilihat dari penunjukkan atau rekomendasi WIKA secara langsung oleh Presiden Widodo dalam sejumlah proyek di Afrika. Hal ini, utamanya, terlihat dari proyek di Niger dan Namibia. Pada kunjungan perdana Presiden Niger Mahamadou Issoufou ke Indonesia pada tahun 2017, Presiden Widodo memberikan dukungan penuh pada pengembangan proyek infrastruktur di Niger, dengan merekomendasikan WIKA untuk menangani potensi pembangunan di negara tersebut. Kunjungan ini ditujukan untuk mendalami dan menyusun mekanisme hubungan bilateral antara Niger dan Indonesia. Menurut Kemlu, kerja sama ini dapat menjadi media bagi Indonesia untuk mendekati asosiasi kerja sama ekonomi regional Economic Community of West African States (ECOWAS), mengingat Niger adalah anggota dari organisasi beranggotakan 15 negara tersebut (Hasan, 2017). Sementara itu, pertemuan antara Presiden Widodo dengan Presiden Namibia Hage Gottfried Geingob pada 2018 menyepakati peningkatan kerja sama di bidang infrastruktur. Secara khusus, Presiden Widodo mendorong WIKA membangun 2.000 unit rumah susun di Namibia.

Selain itu, perencanaan tersentral juga terlihat dari kehadiran menteri dan pejabat tinggi pemerintah dalam penandatanganan kontrak bisnis WIKA. Kehadiran Menlu Marsudi pada penandatanganan kontrak pembangunan kawasan terpadu antara WIKA dengan Senegal dan kehadiran Menteri Koordinator Maritim dan Investasi Indonesia Luhut Binsar Pandjaitan pada penandatangan proyek infrastruktur industri di Tanzania menunjukkan pentingnya investasi WIKA di Afrika bagi pemerintah, sedrta keterlibatan pemerintah dalam ekspansi yang dilakukan perusahaan tersebut. Penandatanganan kontrak bisnis di Tanzania juga dihadiri oleh pejabat tinggi Kemlu (lihat Tabel 1). 
Terakhir, perencanaan ekspansi yang tersentralisasi dari pemerintah terlihat dari diadakannya dua forum multilateral dengan negara-negara Afrika selama Rezim Presiden Widodo. Forum pertama adalah Indonesia-Africa Forum (IAF) yang diadakan pada tahun 2018. Dalam forum tersebut, Kemlu dan Kementerian Perdagangan memfasilitasi investor Indonesia menyelenggarakan pameran produk dan bertatap muka dengan rekanan potensial untuk membina kerja sama. Forum tersebut dihadiri oleh 550 peserta dari 53 negara. Forum kedua, IAID, diadakan pada tahun 2019 dan merupakan forum yang dilakukan untuk meneruskan forum sebelumnya dan secara khusus membahas mengenai potensi pembangunan infrastruktur. WIKA merupakan salah satu perusahan yang diboyong oleh pemerintah dalam kedua acara tersebut, dan membukukan sejumlah komitmen yang menjadi pintu masuk bagi perusahaan konstruksi tersebut di Afrika. Hasil kedua forum ini akan dibahas lebih jauh di bagian berikutnya.

\section{Diplomasi ekonomi dalam upaya pembukaan pasar}

Diplomasi ekonomi merupakan salah satu konsep yang kerap dibahas dalam studi kapitalisme negara. Peran dan bentuk intervensi Pemerintah Indonesia dalam menyokong ekspansi WIKA ke Afrika dapat dilihat dari diplomasi ekonomi yang dilaksanakan dalam rangka pembukaan pasar baru. Upaya-upaya tersebut melingkupi pembentukan forum multilateral dengan negara-negara Afrika, pelibatan WIKA dalam diskusi yang bersifat bilateral, serta upaya pembentukkan hubungan baik antara WIKA, Indonesia, dan negara-negara sasaran ekspansi. Ringkasnya, merujuk pada kajian literatur teoretis yang telah dijabarkan di atas, negara melaksanakan varian diplomasi ekonomi - yakni diplomasi korporasi - dalam upaya mengenalkan, mempromosikan, dan membuka pasar bagi ekspansi WIKA ke Afrika. Untuk menjabarkan upaya pembukaan pasar dan pengenalan WIKA sebagai simbol negara, tulisan ini akan menggunakan variabel engagement, familiarity, dan acceptance yang telah dibahas secara singkat dalam kajian teoretis.

Tulisan ini berargumen bahwa terkait variabel engagement, Rezim Presiden Widodo mengenalkan WIKA sebagai national champion dalam sektor konstruksi lewat pelaksanaan dua forum dengan negara-negara kontingen Afrika, yaitu IAF dan IAID di Bali. Forum IAF yang diadakan pada tahun 2018 menghasilkan kesepakatan bisnis sebesar US\$586 juta. Menteri Luar Negeri (Menlu) Indonesia Retno Marsudi mengungkapkan bahwa WIKA, sebagai salah satu BUMN yang diboyong pemerintah dalam acara ini, menjadi perusahaan yang paling produktif dalam perhelatan tersebut. Dalam forum tersebut, WIKA menghasilkan komitmen dengan 13 negara, termasuk di antaranya Aljazair, Niger, dan Mozambik. Sementara itu, IAID yang diselenggarakan oleh pemerintah Indonesia pada tahun 2019 menjadi kelanjutan dari diskusi dalam IAF dan menghasilkan komitmen bisnis sebesar US\$822 juta. Dari total angka tersebut, sebesar US\$650 juta atau hampir 80\% merupakan komitmen antara negara-negara peserta dengan WIKA. Kesepakatan bisnis tersebut meliputi komitmen senilai \$10 juta dengan Niger untuk membangun Istana Kepresidenan, kesepakatan dengan Pantai Gading untuk pembangunan perumahan rakyat sebesar US\$200 juta, dan kesepakatan dengan Tanzania untuk pembangunan berbagai proyek 
konstruksi senilai \$190 juta. Selain itu, WIKA juga membuat kesepakatan dengan LPEI dan Pemerintah Senegal untuk pembangunan kawasan bisnis terpadu senilai US\$250 juta (WIKA, 2019c).

Pelibatan WIKA oleh negara tidak berhenti hanya sekadar dalam forum-forum multilateral. Hasil penelusuran tulisan ini menemukan bahwa WIKA juga kerap diikutsertakan atau direkomendasikan dalam pertemuan-pertemuan bilateral. Seperti yang telah dijabarkan sebelumnya, Presiden Widodo secara langsung merekomendasikan kinerja WIKA pada Niger dan Namibia. Selain itu, WIKA turut diboyong pada kunjungan Direktorat Asia Pasifik Kemlu RI ke Niger, dalam rangka penandatangan Nota Kesepahaman tentang Pembentukkan Komite Gabungan untuk Pengembangan Kerjasama Bilateral kedua negara pada November 2017 (Kemlu RI, 2017a).

Upaya memuluskan jalannya ekspansi perusahaan Indonesia di Afrika tidak hanya dilakukan lewat kerja sama korporatis, namun juga melalui jalur diplomasi. Mengutip situs Kemlu (2019b), guna menunjang diplomasi ekonomi, Indonesia melakukan penguatan infrastruktur diplomasi di Afrika. Hal ini dilakukan dengan pembukaan perwakilan RI di Kamerun, untuk memfokuskan dan mengefektifkan diplomasi Indonesia di kawasan Afrika Barat dan Afrika Tengah. Indonesia juga meningkatkan jumlah konsul kehormatan RI di Afrika sebesar 70\% menjadi 22 konsul kehormatan pada tahun 2019. Tujuan dari pembentukkan konsul kehormatan ini, menurut Kemlu, adalah menjadi perpanjangan tangan Pemerintah Indonesia untuk memastikan tersalurkannya dukungan kepada seluruh pemangku kepentingan Indonesia dalam memperkuat kerja sama di Afrika. Hal ini juga erat dengan variabel diplomasi korporasi yang kedua, yaitu familiarity.

Variabel familiarity berkaitan dengan pembentukan perusahaan sebagai simbol perwakilan negara di entitas tujuan ekspansi, dalam upaya pembukaan pasar di negara tersebut. Tulisan ini berargumen bahwa nilai-nilai patriotis yang telah dibahas pada bagian sebelumnya erat terkait dengan variabel ini. Pernyataan-pernyataan tersebut menempatkan WIKA sebagai national champion yang mewakili Indonesia di tanah Afrika, sesuai dengan keunggulan kompetitif Indonesia dalam pembangunan infrastruktur. Hal ini misalnya terlihat dari bagaimana mantan Direktur Utama WIKA Bintang Prabowo menyatakan bahwa "WIKA siap menjadi simbol keunggulan infrastruktur Indonesia dan menjadi perusahaan yang mampu bersaing di pasar internasional" (WIKA, 2017b).

Terakhir, variabel acceptance of the corporation memiliki indikator bahwa negara host harus dapat melihat persamaan fundamental antara masyarakatnya dan perwakilan bisnis asing di negara tersebut. Tulisan ini mengidentifikasi dua bentuk acceptance beroperasinya perusahaan asal Indonesia di Afrika: kesamaan nilai dan kesamaan kepentingan. Upaya penyamaan nilai ini, misalnya, bisa dilihat dari pernyataan Presiden Widodo dalam pertemuannya dengan Presiden Niger Mahamadou Issoufou pada tahun 2017 yang menekankan adanya ikatan kuat antara Indonesia dan Niger melalui tiga aspek, yaitu persaudaraan Islam, demokrasi dan kebebasan beragama, serta kondisi kedua negara sebagai negara berkembang (Ihsanuddin, 2017). Selain itu, Indonesia juga kerap menekankan kedekatan sejarah dan politik antara Indonesia dan Afrika 
sebagai negara bekas jajahan dan keterlibatan kedua pihak dalam gerakan anti-kolonialisme dalam Konferensi Asia Afrika (KAA), serta perlunya melangkah lebih jauh dengan mengeksplorasi kedekatan ekonomi antara keduanya. Selain itu, pengiriman lebih dari 1000 orang "Duta Bangsa" atau tenaga kerja WIKA oleh Kementerian BUMN ke negara-negara Afrika juga menjadi indikator upaya negara untuk menyebarkan nilai yang diampu WIKA dan Indonesia, serta membentuk sense of belonging tenaga kerja di negara tujuan dengan perusahaan dan membina keahlian tenaga kerja setempat (Kemlu RI, 2018b).

Indonesia dan negara-negara Afrika juga memiliki kesamaan tujuan. Seperti dijabarkan pada bagian sebelumnya, Indonesia memiliki kepentingan untuk membuka pasar baru, mengembangkan keunggulan kompetitif WIKA, serta mencari pemasukan untuk menambah devisa negara. Di sisi lain, negara-negara Afrika membutuhkan pembangunan infrastruktur, serta ketersediaan modal yang memadai untuk membiayai pembangunan ini. Isu terkait modal ini akan lebih spesifik dibahas di bagian setelah ini.

\section{Penyediaan modal}

Salah satu unsur mendasar yang kerap disebutkan berulang dalam kajian state capitalism adalah fasilitasi modal bagi BUMN, baik berupa subsidi, suntikan dana, maupun bantuan pinjaman dari bank milik pemerintah dan lembaga pembiayaan nasional. Hasil penelusuran tulisan ini menemukan bahwa dalam operasi di dalam negeri, WIKA mengandalkan proyek-proyek yang yang pendanaannya berasal dari APBN, serta mengalokasikan modal pengeluarannya untuk proyek strategis di luar negeri (WIKA, 2018a). Selain itu, pemerintah juga telah mencanangkan sejumlah kebijakan untuk menyuntikkan dana bagi WIKA agar bisa menjalankan fungsinya sebagai penyedia infrastruktur di dalam negeri. Hal ini, misalnya, dilakukan lewat program Penyertaan Modal Negara (PMN) yang dilakukan untuk membiayai proyek-proyek infrastruktur pada tahun 2016 silam. WIKA menjadi penerima dana terbesar di antara BUMN lainnya dengan mengantongi Rp 4 triliun. Untuk menyeimbangkan proporsi antara kepemilikan saham pemerintah dengan publik, WIKA kemudian melaksanakan right issue dan meraih dana Rp 2.1 triliun (WIKA, 2017). Hal ini memberikan keleluasaan finansial bagi WIKA untuk dapat berekspansi ke mancanegara, di tengah kencangnya pembangunan infrastruktur di dalam negeri.

Kebutuhan modal menjadi tantangan yang dihadapi WIKA dan negara-negara Afrika dalam kerja sama pembangunan infrastruktur. Pemerintah Indonesia berusaha menjembatani persoalan ini dengan memberdayakan LPEI. Pemberdayaan ini dilakukan dengan skema National Interest Account (NIA). NIA merupakan skema pinjaman yang diberikan oleh pemerintah untuk proyek yang dianggap sulit namun penting bagi negara (LPEI, n.d.). Hal ini lagi-lagi menunjukkan bagaimana negara menempatkan WIKA sebagai perusahaan unggulan.

Pada Maret 2019, lewat skema NIA tersebut, LPEI memberikan Kredit Modal Kerja Ekspor (KMKE) kepada WIKA untuk menyokong proyek pembangunan pemukiman di Aljazair. KMKE 
ini juga ditujukan untuk membiayai proyek-proyek WIKA di Afrika serta kawasan lainnya. Menteri Keuangan Sri Mulyani Indrawati menyatakan bahwa fasilitas pembiayaan ini disalurkan kepada WIKA sebagai misi untuk mengekspor jasa konstruksi ke pasar non-tradisional, serta meningkatkan kapasitas perekonomian dan industri untuk penetrasi ke pasar internasional (Kemkeu RI, 2019a). Menurut Kementerian Keuangan, program tersebut merupakan manifestasi dukungan negara dalam peningkatan ekspor ke pasar baru. Dukungan ini secara legal ditetapkan lewat Keputusan Menteri Keuangan (KMK) Republik Indonesia Nomor 1/KMK.08/2019 tentang Penugasan Khusus kepada LPEI untuk Mendorong Ekspor ke Negara Kawasan Afrika, Asia Selatan, dan Timur Tengah.

Dalam perhelatan IAID, LPEI dan WIKA juga menandatangani sejumlah kesepakatan pembiayaan dengan skema buyer's credit. Berbeda dengan NIA, skema ini menempatkan pembeli jasa perusahaan Indonesia di luar negeri sebagai debitur. Kesepakatan yang ditandatangani di antaranya adalah perjanjian kerangka kerja bersama pemerintah Senegal dan Badan Pembangunan Nasional Senegal (AGPBE), untuk membangun kawasan bisnis terpadu senilai US\$250 juta. Selain itu, LPEI dan WIKA juga menandatangani perjanjian kerangka kerja dengan Pantai Gading untuk pembangunan dan pengembangan 20.000 unit rumah susun dengan nilai total mencapai US\$200 juta. LPEI, WIKA, dan Tanzania juga menyepakati proyek senilai US\$190 juta untuk membangun pelabuhan terminal liquid di Zanzibar (Kemkeu RI, 2019b). Direktur Eksekutif LPEI Sinthya Roesli mengatakan, realisasi kesepakatan itu merupakan wujud upaya pemerintah untuk mendorong eksportir menembus pasar potensial atau non-tradisional market dan karenanya, BUMN konstruksi yang memiliki kapasitas dan reputasi internasional seperti WIKA didorong untuk membuka jalan menuju pasar baru tersebut (LPEI, 2019).

\section{Simpulan}

Melalui kajian mendalam terhadap sejumlah literatur state capitalism, tulisan ini menggunakan tiga variabel dalam upaya membaca peran pemerintah dalam ekspansi WIKA ke Afrika, yaitu perencanaan tersentral, diplomasi ekonomi dalam rangka pembukaan pasar dan legitimasi operasi perusahaan, serta permodalan. Dalam variabel pertama, tulisan ini menemukan bahwa ekspansi WIKA ke Afrika didorong oleh keinginan negara terhadap upaya pembukaan pasar baru, meningkatkan daya saing di tengah kompetisi global, menyebarkan nilai-nilai Indonesia, serta menunjang stabilitas rezim. WIKA menjadi national champion dari sektor yang diunggulkan Rezim Presiden Widodo, yaitu konstruksi dan infrastruktur. Afrika menjadi pilihan yang masuk akal bagi ekspansi WIKA mengingat kekuatan ekonomi Indonesia yang relatif lebih besar, adanya kesamaan identitas, serta kesamaan kepentingan yaitu mencari pasar (Indonesia) dan membangun infrastruktur (Afrika). Perencanaan tersentral ini juga terlihat dari bagaimana pemerintah merancang IAF dan IAID untuk mengenalkan WIKA dan perusahaan-perusahaan lainnya ke Afrika, yang juga menjadi indikator bagi variabel diplomasi ekonomi. Upaya diplomasi untuk membuka pasar juga dilakukan dengan promosi langsung dan pelibatan WIKA dalam agenda 
bilateral, penempatan WIKA sebagai simbol Indonesia di Afrika lewat sejumlah pernyataan patriotis, pengenalan kesamaan nilai, dan pembentukkan konsul kehormatan di Afrika dalam rangka menjembatani perusahaan dengan negara-negara di kawasan tersebut. Terakhir, pemerintah Indonesia juga berperan dalam upaya memenuhi permodalan yang dibutuhkan oleh WIKA dan negara-negara Afrika dengan suntikan dana bagi WIKA dan lewat skema NIA LPEI.

Penulis melihat masih besarnya ruang penelitian mengenai peran negara dalam ekspansi BUMN ke pasar global, mengingat kencangnya arus ekspansi yang tengah dilakukan oleh sejumlah BUMN Indonesia. Kajian sektoral terhadap peran negara dalam ekspansi dari sektor riil, sektor energi, serta perdagangan masih dapat dikaji lebih jauh. Selain itu, mengingat bahwa kajian literatur terhadap sejumlah pemikir state capitalism menunjukkan adanya variasi implementasi di berbagai negara, tulisan ini juga melihat adanya potensi mengembangkan konsep state capitalism yang secara khusus mengkaji keunikan praktek keterlibatan pemerintah dalam perekonomian Indonesia.

\section{Referensi}

Alami, I., \& Dixon, A. D. (2019). State capitalism(s) redux? Theories, tensions, controversies. Competition \& Change, O(0), 1-25. https://doi.org/10.1177/1024529419881949

Babic, M., Garcia-Bernardo, J., \& Heemskerk, E. M. (2019). The rise of transnational state capital: state-led foreign investment in the 21st century. Review of International Political Economy, 27(3), 433-475. https://doi.org/10.1080/09692290.2019.1665084

Balaam, D., \& Dillman, B. (2014). Wealth and Power: The Mercantilist Perspective. In Introduction to International Political Economy (pp. 53-77). Pearson Education, Inc. https://doi.org/10.4324/9781315663838

Bieling, H.-J. (2007). The Other Side of the Coin: Conceptualizing the Relationship between Business and the State in the Age of Globalisation. In Business and Politics (Vol. 9, Issue 3). https://doi.org/10.2202/1469-3569.1187

Bremmer, I. (2010). The End of The Free Market: Who Wins the War Between States and Corporations? Penguin Group.

Carney, R. W. (2015). The stabilizing state: State capitalism as a response to financial globalization in one-party regimes. Review of International Political Economy, 22(4), 838873. https://doi.org/10.1080/09692290.2014.958091

Carney, R. W., \& Hamilton-Hart, N. (2015). What Do Changes in Corporate Ownership in Indonesia Tell Us? Bulletin of Indonesian Economic Studies, 51(1), 123-145. https://doi.org/10.1080/00074918.2015.1016570

Carney, R. W., \& Witt, M. A. (2014). The Role of the State in Asian Business Systems (Issue October 2018). Oxford Handbooks Online. https://doi.org/10.1093/oxfordhb/9780199654925.013.025

Chen, H., Li, X., Zeng, S., Ma, H., \& Lin, H. (2016). Does state capitalism matter in firm internationalization? Pace, rhythm, location choice, and product diversity. Management Decision, 54(6), 1320-1342. https://doi.org/10.1108/MD-10-2015-0458

Cuervo-Cazurra, A. (2017). State-owned Multinationals: Governments in Global Business. 
Palgrave Macmillan.

Daniele, V. (2011). Natural resources and the "quality" of economic development. Journal of Development Studies, 47(4), 545-573. https://doi.org/10.1080/00220388.2010.506915

Duckett, J. (2007). The emergence of the entrepreneurial state in contemporary China. February 2015, 37-41. https://doi.org/10.1080/09512749608719178

Huat, C. B. (2015). State-owned enterprises, state capitalism and social distribution in Singapore. The Pacific Review, August. https://doi.org/10.1080/09512748.2015.1022587

Kementerian BUMN. (n.d.). Perkembangan Jumlah BUMN Periode 2004-2007. Diambil dari http://bumn.go.id/halaman/0-Statistik-Jumlah-BUMN

Kementerian BUMN. (13 Juni 2019). 4 BUMN Masuk Daftar Perusahaan Publik Terbesar [Siaran pers]. Diambil dari http://bumn.go.id/berita/1--4-BUMN-Masuk-Daftar-Perusahaan-PublikTerbesar

Kemkeu RI. (28 Maret 2019a). Pembiayaan Penugasan Khusus, Dorong Peningkatan Ekspor ke Negara Non Tradisional [Siaran pers]. Diambil dari https://www.kemenkeu.go.id/publikasi/berita/pembiayaan-penugasan-khusus-dorongpeningkatan-ekspor-ke-negara-non-tradisional/

Kemkeu RI. (21 Oktober 2019b). LPEI Gandeng PT WIKA dan PT DI Lebarkan Pembiayaan Hingga Afrika [Siaran pers]. Diambil dari https://www.kemenkeu.go.id/publikasi/berita/lpei-gandeng-pt-wika-dan-pt-di-lebarkanpembiayaan-hingga-ke-afrika/

Kemlu RI. (n.d.). What is The Indonesia Africa Forum? Retrieved from https://iaf.kemlu.go.id/ Kemlu

RI.

(2015).

Diambil

dari https://kemlu.go.id/download/L3NpdGVzL3B1c2F0L0RvY3VtZW50cy9SZW5zdHJhJTIwQIB QSyUyMDIwMTUtMjAxOS5wZGY=

Kemlu RI. (2018a). Laporan Kinerja Tahun 2017. Diambil dari https://kemlu.go.id/portal/id/read/223/akip/laporan-kinerja-kemenlu

Kemlu RI. (2018b, 30 November). Inilah Kunci Sukses WIKA Masuk Afrika. Diunduh dari https://diplomasiekonomi.kemlu.go.id/index.php/kisahsukses3

Kemlu RI. (2019a). Laporan Kinerja Tahun 2018. Diambil dari https://kemlu.go.id/portal/id/read/223/akip/laporan-kinerja-kemenlu

Kemlu RI. (2019b, August 22). Diplomasi Ekonomi Iaid 2019 Hasilkan Kesepakatan Bisnis Senilai 822 Juta Usd: Portal Kementerian Luar Negeri Republik Indonesia. Diambil dari https://kemlu.go.id/portal/id/read/542/berita/diplomasi-ekonomi-iaid-2019-hasilkankesepakatan-bisnis-senilai-822-juta-usd

Kim, K. (2019). Indonesia's Restrained State Capitalism: Development and Policy Challenges. Journal of Contemporary Asia, 2336. https://doi.org/10.1080/00472336.2019.1675084

Klimina, A. (2014). Finding a positive vision for state capitalism. Journal of Economic Issues, 48(2), 421-430. https://doi.org/10.2753/JEI0021-3624480216

Kröger, M. (2012). Neo-mercantilist Capitalism and Post-2008 Cleavages in Economic Decisionmaking Power in Brazil. Third World Quarterly, 33(5), 887-901. https://doi.org/10.1080/01436597.2012.674703

Kurlantzick, J. (2016). State capitalism: How The Return of Statism is Transforming The World. Oxford University Press. https://doi.org/10.1080/25739638.2018.1511122

Li, M. H., Cui, L., \& Lu, J. (2014). Varieties in state capitalism: Outward FDI strategies of central and local state-owned enterprises from emerging economy countries. Journal of International Business Studies, 45(8), 980-1004. https://doi.org/10.1057/jibs.2014.14 
Meckling, J., Kong, B., \& Madan, T. (2015). Oil and state capitalism : government-firm coopetition in China and India Oil and state capitalism. Review of International Political Economy, October. https://doi.org/10.1080/09692290.2015.1089303

Musacchio, A., Lazzarini, S. G., \& Aguilera, R. V. (2015). New varieties of state capitalism: Strategic and governance implications. Academy of Management Perspectives, 29(1), 115131. https://doi.org/10.5465/amp.2013.0094

Niall Ferguson. (2012). We're All State Capitalists Now. Foreign Policy. https://foreignpolicy.com/2012/02/09/were-all-state-capitalists-now/

Nölke, A. (Ed.). (2014). Multinational Corporations from Emerging Markets: State Capitalism 3.0. Palgrave Macmillan.

Nölke, A., Brink, T., \& Claar, S. (2015). Domestic structures, foreign economic policies and global economic order: Implications from the rise of large emerging economies. European Journal of International Relations, 21(3), 538-567. https://doi.org/10.1177/1354066114553682

OECD. (2016). State-Owned Enterprises as Global Competitors: A Challenge or an Opportunity? https://doi.org/10.1787/9789264262096-5-en

Okano-Heijmans, M. (2011). Conceptualizing Economic Diplomacy: The Crossroads of International Relations, Economics, IPE and Diplomatic Studies. In Economic Diplomacy: Economic and Political Perspective (pp. 7-36). Martinus Nijhoff Publishers.

Ordeix-Rigo, E., \& Duarte, J. (2009). From public diplomacy to corporate diplomacy: Increasing corporation's legitimacy and influence. American Behavioral Scientist, 53(4), 549-564. https://doi.org/10.1177/0002764209347630

Redding, K. S., Xie, E., \& Tang, Q. (2018). Institutionalization to Internationalization: The Transformational Dynamics and Outward Foreign Direct Investment of State-Owned Enterprises. International Journal of Public Sector Management, 31(2), 241-264. https://doi.org/10.1108/IJPSM-02-2017-0040

Sperber, N. (2019). The many lives of state capitalism: From classical Marxism to free-market advocacy. History of the Human Sciences, 32(3), 100-124. https://doi.org/10.1177/0952695118815553

Taylor, I. (2014). State capitalism and the oil sector in Africa. Review of African Political Economy, O(0), 1-17. https://doi.org/10.1080/03056244.2013.864630

Tsai, K. S., \& Naughton, B. (2020). State Capitalism and the Chinese Economic Miracle: Vol. $i$.

Weiss, L. (Ed.). (2003). States in the Global Economy: Bringing Domestic Institution Back In. Cambridge University Press. PT Wijaya Karya Tbk. (2016). Laporan Tahunan 2015. Diambil dari http://wika.listedcompany.com/misc/ar2015/ar2015.pdf

WIKA. (16 Oktober 2017). Pemerintah Niger Jajaki Peluang Kerjasama Infrastruktur dengan WIKA [Siaran pers]. Diambil dari https://www.wika.co.id/po-content/po-upload/siaranpers--pemerintah-niger-jajaki-peluang-kerjasama-infrastruktur-dengan-wika-403584file.pdf

WIKA. (2018a). Laporan Tahunan 2017. Diambil dari http://investor.wika.co.id/misc/WIKA-AR2017.pdf

WIKA. (13 Maret 2018b). Pemerintah Afghanistan Tawarkan Peluang Kerjasama Pembangunan Infrastruktur ke WIKA [Siaran pers]. Diambil dari https://www.wika.co.id/po-content/poupload/pemerintah-afghanistan-tawarkan-peluang-kerjasama-pembangunan-infrastrukturke-wika-491912-file.pdf

WIKA. (16 Maret 2018c). WIKA Bangun 1.400 Rumah di Aljazair [Siaran pers]. Diambil dari https://www.wika.co.id/po-content/po-upload/wika-bangun-1400-rumah-di-aljazair- 
399376-file.pdf

WIKA. (25 Oktober 2018d). Gubernur Provinsi Skikda Dukung Perluasan Pasar WIKA di Aljazair [Siaran pers]. Diambil dari https://www.wika.co.id/po-content/po-upload/kunjungangubernur-skikda-aljazair-165359-file.pdf

WIKA. (2019a). Laporan Tahunan 2018. Diambil dari http://investor.wika.co.id/misc/AR/WIKAAR2018-Bahasa.pdf

WIKA. (29 April 2019b). Torehkan Penjualan Rp6,50 Triliun, Laba Bersih WIKA Tumbuh 58,45\% [Siaran pers]. Diambil dari https://www.wika.co.id/po-content/po-upload/siaranpers-laporan-keuangan-q12019-wika-867675-file.pdf

WIKA. (2 Desember 2019c). WIKA-AGPBE Tandatangani Kontrak Tahap 1 Goree Tower Project Senegal Pilot Project Prestisius BUMN Karya di Afrika Barat [Siaran pers]. Diambil dari https://www.wika.co.id/po-content/po-upload/siaran-pers-bersama-wika--lpei-goree-towersenegalfinal-924416-file.pdf

WIKA. (18 Desember 2019d). Bangun Istana Kepresidenan Niger, WIKA Perkuat dan Perluas Pasar di Afrika Barat [Siaran pers]. Diambil dari https://www.wika.co.id/po-content/poupload/siaran-pers-bangun-istana-kepresidenan-niger-wika-perkuat-dan-perluas-pasar-diafrika-barat-1-658175-file.pdf

WIKA. (18 Desember 2019e). WIKA Initiates Cooperation in Infrastructure Development with Tanzania [Siaran pers]. Diambil dari https://www.wika.co.id/detailpost/wika-initiatescooperation-in-infrastructure-development-with-tanzania

WIKA. (18 Desember 2019f). WIKA Rintis Kerja Sama Jutaan Dollar, untuk Pembangunan Infrastruktur dengan Tanzania [Siaran pers]. Diambil dari https://www.wika.co.id/pocontent/po-upload/siaran-pers-wika-jajaki-kerja-sama-jutaan-dollar-untuk-banguninfrastruktur-tanzania--942075-file.pdf 